\title{
Pengaruh Penggunaan Nano Kalsium Terhadap Produksi Tomat (Lycopersicum esculentum Mill)
}

\author{
Author(s): Aqidatul Izzah ${ }^{(1)}$; Iswahyudi ${ }^{(1) *}$; Kelik Perdana Windra Sukma ${ }^{(1)}$ \\ (1) Fakultas Pertanian, Universitas Islam Madura \\ * Corresponding author: iswahyudi.uim@gmail.com
}

\begin{abstract}
ABSTRAK
Tanaman tomat membutuhkan hara untuk pertumbuhannya, salah satunya kalsium. Kalsium merupakan makronutrien penting untuk petumbuhan sel dan buah. Pada penelitian ini pupuk kalsium yang diaplikasikan pada tanaman tomat dalam bentuk nanokalsium dengan 3 fasa yang berbeda, yaitu aragonit, kalsit dan vaterit. Penelitian ini bertujuan untuk mengetahui pengaruh pengaplikasian dari ketiga fasa tersebut dan konsentrasi nano kalsium yang berbeda terhadap produksi tomat. Penelitian ini dilaksanakan di Desa Kadur Kabupaten Pamekasan. Tanaman tomat ditanam pada polibag dan disusun dengan menggunakan Rancangan Acak Kelompok (RAK). Perlakuan terdiri dari penggunaan tiga fasa nano kalsium (Aragonit, Kalsit dan Vaterit) dan dosis penggunaan ( 0,$25 ; 0,5$; dan 0,75 gram/tanaman). Masing-masing perlakuan tiga kali ulangan. Parameter yang diamati meliputi tinggi tanaman, jumlah daun, luas indeks daun dan berat total buah. Data di analisis menggunakan Anova dan apabila berbeda nyata dilanjutkan dengan uji DMRT 5\%. Hasil penelitian menunjukkan perlakuan fasa nano kalsium, dosis dan interaksi keduanya menurunkan jumlah daun dan indeks luas daun.
\end{abstract}

\section{Kata Kunci:}

Aragonit;

Kalsit;

Nano kalsium;

Vaterit;

Tomat;

Keywords: $\quad$ Tomato needs nutrient for it growth, such as calcium. Calcium is an important

Aragonite; macronutrient for cell and fruit growth. This reasearch used nano-calcium on three phase (aragonite, calcite and vaterite). This reasearch objective was to know the effect

Calcite; of the three nano-calcium phases to tomato production. The research conducted on

Nano-calsium; Kadur Village, Pamekasan regency. Tomato was planted on polybag, arranged by

Vaterite; Randomized Complete Block Design (RCBD). Treatment consists of nano-calcium phase

Tomato; treatment replicated three times. The observed parameters were plant height, leaves count, leaf area index, and fruit weight. The data were analyzed by anova factorial RCBD and Duncan Means Range Test (DMRT) 5\%. The result showed that the aplication nano-calcium phase, dosage and its interaction gave significantly decreased leaves count and leaf area index. 


\section{PENDAHULUAN}

Tanaman tomat juga membutuhkan unsur hara makro dan unsur hara mikro. Pupuk merupakan sarana produksi pertanian yang memiliki peran penting untuk mendapatkan hasil yang optimal. Pemupukan bertujuan untuk menambah unsur hara tertentu didalam tanah yang habis terserap oleh tanaman saat panen (Wibowo \& Kalatham, 2017). Unsur hara makro yang dibutuhkan oleh tanaman tomat salah satunya yaitu kalsium. Kalsium merupakan salah satu nutrisi penting makro utama untuk pertumbuhan tanaman. Kalsium memiliki peranan penting dalam menjaga kualitas buah, menjaga keutuhan sel, dan pertumbuhan buah (Ayyub et al., 2012). (Huang et al., 2003) menyatakan, pemberian kalsium dapat mengurangi pecah buah pada tanaman leci. Kalsium juga mendorong terbentuknya buah dan biji yang sempurna (Novizan, 2002).

Bentuk bentuk pupuk kalsium yaitu kalsium Nitrat $\mathrm{Ca}\left(\mathrm{NO}_{3}\right)_{2}$, Amonium nitrat kapur $\mathrm{NH}_{4} \mathrm{NO}_{3} . \mathrm{CaO}$, Gips (gipsum), Kalsium metafosfat $\mathrm{Ca}(\mathrm{PO} 4)_{2}$, Dolomit $\left(\mathrm{CaCO}_{3} . \quad \mathrm{MgCO}_{3}\right)$ (Rosmarkam \& Yuwono, 2002). Dalam bidang pertanian pada umumnya pupuk kalsium di aplikasikan dalam bentuk butiran biasa, bentuk tepung atau dalam bentuk cair, namun dalam penelitian ini pupuk kalsium akan di aplikasikan dalam bentuk nano kalisium dengan 3 fasa yang berbeda, yaitu aragonit, kalsit dan vaterit (Andi et al., 2012). Dalam penelitian (Hua et al., 2015) nano-Ca menunjukkan kinerja yang lebih baik dalam pemupukan, perlindungan tanaman, dan pengendalian hama terhadap koloid Ca. Serta gula larut dan protein tinggi dari bagian-bagian areal tanaman di bawah perawatan nano kalsium (Liu et al., 2005). Sehingga perlu dilakukan penelitian dengan perlakuan dari ketiga fasa nano kalsium tersebut (aragonite, kalsit, dan vaterit) dengan cara diaplikasikan terhadap tanaman tomat. Tujuan dari penelitian ini untuk mengetahui pengaruh pengaplikasian dari ketiga fasa dan konsentrasi nano kalsium yang berbeda terhadap budidaya tanaman tomat.

\section{METODOLOGI}

Penelitian dilakukan di Desa Kadur, Kecamatan Kadur, Kabupaten Pamekasan. Penelitian dilaksanakan pada bulan Maret Juni 2019. Tanaman tomat yang telah disemai pada media arang sekam dan cocopeat selama 20 hari, ditanam pada polybag dan disusun menggunakan Rancangan Acak Kelompok (RAK). Media yang digunakan adalah campuran arang sekam, cocopeat, tanah dan pupuk kandang dengan perbandingan 1:1:1:1 yang terdiri dari penggunaan tiga fase Nano Kalsium (kalsit, vaterit dan aragonit) dan masingmasing diaplikasikan dengan dosis 0,25 gr, 0,5 gr, 0,75 gr. Media tanam yang digunakan dalam penanaman tomat yaitu campuran antara cocopeat, arang sekam, tanah dan pupuk kandang dengan perbandingan 1:1:1:1. Pemupukan menggunakan Urea dan KCL pada 7 hst (hari setelah tanam). Aplikasi nanokalsium dilakukan pada minggu ke 3,6, dan 9 hst. Nano-kalsium yang diaplikasikan yaitu aragonit, kalsit dan vaterit dengan konsentrasi masing-masing 0,$25 ; 0,5$; dan 0,75 gram per tanaman. masing-masing perlakuan diulang tiga kali.

\section{HASIL DAN PEMBAHASAN Tinggi Tanaman Tomat}

Pertambahan tinggi tanaman merupakan bentuk peningkatan pembelahan sel-sel akibat adanya asimilat yang meningkat (Harjanti et al., 2014). Untuk hasil pengamatan tinggi tanaman tomat dapat dilihat pada Tabel 1 . 
Tabel 1. Tinggi tanaman tomat dengan perlakuan nano-kalsium

\begin{tabular}{|c|c|c|c|c|}
\hline $\begin{array}{l}\text { Konsentrasi } \\
\text { Fase Nano-Ca } \\
\end{array}$ & $0 \mathrm{gr}$ & $0,25 \mathrm{gr}$ & $0,5 \mathrm{gr}$ & $0,75 \mathrm{gr}$ \\
\hline Kalsit & $109^{a}$ & $91,166^{\mathrm{a}}$ & $115,166^{a}$ & $112,933^{a}$ \\
\hline Aragonit & $109^{a}$ & $104,150^{\mathrm{a}}$ & $99,167^{\mathrm{a}}$ & $102,700^{a}$ \\
\hline Vaterit & $109^{a}$ & $92,833^{\mathrm{a}}$ & $94,833^{\mathrm{a}}$ & $101,300^{a}$ \\
\hline
\end{tabular}

Keterangan: Nilai rata-rata yang dikuti huruf sama pada baris dan kolom yang sama, tidak berpengaruh pada taraf uji DMRT $5 \%$.

Berdasarkan Tabel 1, perlakuan nano-kalsium tidak berpengaruh terhadap tinggi tanaman tomat. Hasil tersebut berbeda dengan hasil penelitian (Tantawy et al., 2014) yang menunjukkan ada pengaruh nano-kalsium terhadap tinggi tanaman. (Tantawy et al., 2014) menyebutkan aplikasi nano kalsium konsentrasi rendah $(0,5 \mathrm{~g} / \mathrm{l})$ menunjukkan respons yang lebih tinggi dibandingkan dengan konsentrasi terapan tertinggi ( $1 \mathrm{~g} / \mathrm{l})$.

\begin{abstract}
Jumlah Daun
Daun merupakan salah satu organ utama pada tubuh tumbuhan. Merupakan tempat utama fotosintesis, memiliki struktur mulut daun yang berguna untuk pertukaran gas $\mathrm{O}_{2}, \mathrm{CO}_{2}$, dan uap air dari daun kealam sekitar dan sebaliknya (Nugroho et al., 2006). Hasil pengamatan jumlah daun pada penelitian ini dapat dilihat pada Tabel 2.
\end{abstract}

Tabel 2. Jumlah Daun

\begin{tabular}{|c|c|c|c|c|}
\hline $\begin{array}{l}\text { Konsentrasi } \\
\text { Fase Nano-Ca }\end{array}$ & $0 \mathrm{gr}$ & 0,25 gr & $0,5 \mathrm{gr}$ & $0,75 \mathrm{gr}$ \\
\hline Kalsit & $41^{b}$ & $27,000^{a}$ & $39,666^{b}$ & $35,000^{a b}$ \\
\hline Aragonit & $41^{b}$ & $29,000^{\mathrm{ab}}$ & $31,333^{\mathrm{ab}}$ & $35,666^{a b}$ \\
\hline Vaterit & $41^{b}$ & $32,666^{\mathrm{ab}}$ & $35,666^{\mathrm{ab}}$ & $39,666^{b}$ \\
\hline
\end{tabular}

Tabel 2 menunjukkan bahwa perlakuan nano-kalsium menurunkan jumlah daun. Penurunan terbanyak pada perlakuan kalsit 0,25 gr/tanaman. Hasil penelitian tersebut berbeda dengan hasil penelitian (Ayyub et al., 2012) yang menunjukkan bahwa penggunaan pupuk kalsium (bersumber dari $\mathrm{CaCl}_{2}$ ) pada fase pertumbuhan yang berbeda dapat meningkatkan jumlah daun majemuk pada tanaman tomat. Namun sejalan dengan penelitian (Rachmah et al., 2017) bahwa perlakuan pupuk kalsium $\left(\mathrm{CaCO}_{3}\right)$ secara terpisah tidak berpengaruh nyata terhadap jumlah daun.

\section{Indeks Luas Daun}

Indeks luas daun (ILD) adalah variabel yang digunakan untuk menyatakan kondisi daun tanaman yang sangat mempengaruhi proses biofisik tanaman, terutama dalam hubungannya dengan penyerapan radiasi matahari pada proses fotosintesis. indeks luas daun berfungsi untuk menghitung banyaknya radiasi matahari yang diserap daun untuk fotosintesis (Gusmayanti \& Sholahuddin, 2016). Hasil pengamatan indeks luas daun pada penelitian ini dapat dilihat pada Tabel 3. 
Tabel 3. Indeks Luas Daun

\begin{tabular}{|c|c|c|c|c|}
\hline $\begin{array}{l}\text { Konsentrasi } \\
\text { Fase Nano-Ca }\end{array}$ & 0 gr & 0,25 gr & $0,5 \mathrm{gr}$ & $0,75 \mathrm{gr}$ \\
\hline Kalsit & $0,03267^{\mathrm{a}}$ & $0,03467^{a}$ & $0,04700^{b}$ & $0,03033^{a}$ \\
\hline Aragonit & $0,03700^{\mathrm{ab}}$ & $0,02533^{\mathrm{a}}$ & $0,02767^{\mathrm{a}}$ & $0,03267^{\mathrm{a}}$ \\
\hline Vaterit & $0,03600^{\mathrm{ab}}$ & $0,03633^{\mathrm{ab}}$ & $0,05233 \mathrm{~b}$ & $0,05000^{b}$ \\
\hline
\end{tabular}

Keterangan : Nilai rata-rata yang dikuti huruf sama pada kolom yang sama, tidak berpengaruh pada taraf uji DMRT 5\%.

Indeks luas daun dari semua perlakuan nano kalsium dari hari ke 15 sampai hari ke 60 mengalami kenaikan. Namun pada hari ke 75 rata rata mengalami penurunan kecuali pada perlakuan nano kalsium vaterite $0.5 \mathrm{gr}$. Seiring bertambahnya umur tanaman, maka tanaman akan mengalami penuaan dan terjadi kerontokan pada daun (Zakariyya, 2016). Setelah dilakukan uji DMRT 5\% indek luas daun menunjukkan bahwa perlakuan fasa nano kalsium (Aragonit, Kalsit, Vaterit) dan konsentrasi nano kalsium (0.0gr, 0.25gr, 0.5gr, 0.75gr) serta interaksi keduanya memberikan hasil berpengaruh tidak nyata terhadap tinggi tanaman.

\section{KESIMPULAN}

1. Perlakuan fasa dan konsentrasi nano kalsium berpengaruh tidak nyata pada semua parameter pertumbuhan yang diamati.

2. Kecenderungan perlakuan yang terbaik adalah kalsit 0,5 gr yang ditunjukkan oleh parameter tinggi, jumlah daun dan indeks luas daun.

\section{DAFTAR PUSTAKA}

Andi, H. J., Arifin, Z., \& Darminto. (2012). 僉 Fabrikasi Komposit PANi/CaCO3 berbasis Material Alam sebagai Pelapis Anti Korosi. Jurnal Fisika dan Aplikasinya, 8(2), 1-5.

Ayyub, C. M., Pervez, M. A., Shaheen, M.

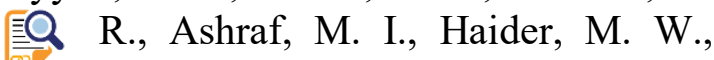
Hussain, S., \& Mahmood, N. (2012). Assessment of various growth and yield attributes of tomato in response to pre-harvest applications of calcium chloride. Pakistan Journal of Life and Social Science, 10(2), 102-105.

Gusmayanti, E., \& Sholahuddin. (2016).

钢 Luas Daun Spesifik dan Indeks Luas Daun Tanaman Sagu di Desa Sungai Ambangah Kalimantan Barat. Paper presented at the SEMIRATA 2015 (pp. 184-192), Pontianak. Universitas Tanjung Pura.

Harjanti, R. A., Tohari, \& Utami, S. N. H. 顽 (2014). Pengaruh takaran pupuk nitrogen dan silika terhadap pertumbuhan awal (Saccharum officinarum L.) pada inceptisol. Vegetalika, 3(2), 35-44.

Hua, K.-H., Wang, H.-C., Chung, R.-S., \& ES Hsu, J.-C. (2015). Calcium carbonate nanoparticles can enhance plant nutrition and insect pest tolerance. Journal of Pesticide Science, 40(4), 208-213.

Huang, X., Wang, H., Li, J., Yin, J., Yuan, E W., Lu, J., \& Huang, H. (2003). An overview of calcium's role in lychee fruit cracking. Paper presented at the II International Symposium on Lychee, Longan, Rambutan and other Sapindaceae Plants 665 (pp. 231-240). 
Liu, X., Zhang, F., Zhang, S., He, X., 琶 Wang, R., Fei, Z., \& Wang, Y. (2005). Responses of peanut to nanocalcium carbonate. Plant Nutrition and Fertitizer Science, 11(3), 385389.

Novizan. (2002). Petunjuk Pemupukan 㰯 yang Efektif. Jakarta: AgroMedia Pustaka.

Nugroho, H., Purnomo, S., \& Sumardi. 嘚 (2006). Struktur dan perkembangan tumbuhan. Depok: Penebar Swadaya.

Rachmah, C., Nawawi, M., \& Koesriharti, 的 K. (2017). Pengaruh Aplikasi Pupuk Kalsium (Caco3) Dan Giberelin Terhadap Pertumbuhan, Hasil, Dan Kualitas Buah Pada Tanaman Tomat (Lycopersicon Esculentum Mill.). Jurnal Produksi Tanaman, 5(3).

Rosmarkam, A., \& Yuwono, N. W. (2002).

尌 Ilmu Kesuburan Tanah. Yogyakarta: Kanisius.

Tantawy, A., Salama, Y., AbdelQ Mawgoud, M., \& Ghoname, A. (2014). Comparison of chelated calcium with nano calcium on alleviation of salinity negative effects on tomato plants. Middle East Journal of Agriculture Research, 3(4), 912-916.

Wibowo, P., \& Kalatham. (2017).

尌 Panduan Praktis Penggunaan Pupuk dan Pestisida. Jakarta: Penebar Swadaya Grup.

Zakariyya, F. (2016). Menimbang indeks

尌 luas daun sebagai variabel penting pertumbuhan tanaman kakao (Vol. 28). Jember: Warta Pusat Penelitian Kopi dan Kakao Indonesia 